\title{
Using Next-Generation Sequencing to Develop Molecular Diagnostics for Pseudoperonospora cubensis, the Cucurbit Downy Mildew Pathogen
}

\author{
S. Withers, E. Gongora-Castillo, D. Gent, A. Thomas, P. S. Ojiambo, and L. M. Quesada-Ocampo
}

First, second, fourth, fifth, and sixth authors: Department of Plant Pathology, North Carolina State University, Raleigh 27695-7616; third author: U.S. Department of Agriculture-Agricultural Research Service, Forage Seed and Cereal Research Unit, and Oregon State University, Corvallis 97331; and fourth and fifth authors: Center for Integrated Fungal Research, North Carolina State University, Raleigh $27695-7567$. Accepted for publication 17 March 2016.

\begin{abstract}
Withers, S., Gongora-Castillo, E., Gent, D., Thomas, A., Ojiambo, P. S., and Quesada-Ocampo, L. M. 2016. Using next-generation sequencing to develop molecular diagnostics for Pseudoperonospora cubensis, the cucurbit downy mildew pathogen. Phytopathology 106:1105-1116.

Advances in next-generation sequencing (NGS) allow for rapid development of genomics resources needed to generate molecular diagnostics assays for infectious agents. NGS approaches are particularly helpful for organisms that cannot be cultured, such as the downy mildew pathogens, a group of biotrophic obligate oomycetes that infect crops of economic importance. Unlike most downy mildew pathogens that are highly host-specific, Pseudoperonospora cubensis causes disease on a broad range of crops

belonging to the family Cucurbitaceae. In this study, we identified candidate diagnostic markers for $P$. cubensis by comparing NGS data from a diverse panel of $P$. cubensis and $P$. humuli isolates, two very closely related oomycete species. $P$. cubensis isolates from diverse hosts and geographical regions in the United States were selected for sequencing to ensure that candidates were conserved in P. cubensis isolates infecting different cucurbit hosts. Genomic regions unique to and conserved in $P$. cubensis isolates were identified through bioinformatics. These candidate regions were then validated using PCR against a larger collection of isolates from P. cubensis, $P$. humuli, and other oomycetes. Overall seven diagnostic markers were found to be specific to $P$. cubensis. These markers could be used for pathogen diagnostics on infected tissue, or adapted for monitoring airborne inoculum with real-time PCR and spore traps.
\end{abstract}

In the past decade, a number of plant pathogens have emerged in the United States causing significant damage in agricultural and natural ecosystems and threatening food security (Fisher et al. 2012). Several recent epidemics have been caused by oomycete pathogens such as the hemibiotroph Phytophthora infestans (Fry et al. 2015), the causal agent of late blight of potato and tomato, and obligate plant pathogens within the family Peronosporaceae that cause downy mildew (Cohen et al. 2015; Gascuel et al. 2015; Holmes et al. 2015). Downy mildew pathogens include diverse genera such as Pseudoperonospora spp. (Gent and Ocamb 2009; Holmes et al. 2015), Plasmopara spp. (Gascuel et al. 2015), Peronospora spp. (Roberts et al. 2009; Testen et al. 2013), and Bremia spp. (Michelmore and Wong 2008) that infect economically important crops and are usually host-specific due to their biotrophic nature. Diagnostic tools for oomycete pathogens range from visual inspection to culturing, serology, and PCR-based tests (Martin et al. 2012). Due to their inability to grow in media and, consequentially, a lack of genomic resources for marker development, downy mildew pathogen diagnostics has mainly been performed by visual inspection of pathogen structures on infected plants (Holmes et al. 2015). However, signs of the pathogen and symptoms of the disease are usually detected when the disease is at advanced stages ( $>30 \%$ severity, Fig. 1) and control strategies, such as fungicide applications, are less effective (Gent et al. 2015; Homa et al. 2014; Ojiambo et al. 2010). In addition, while the main dispersal mechanism of downy mildew pathogens is through airborne sporangia that can travel several miles on wind currents, several downy mildew pathogens are known to be seedborne

Corresponding author: L. M. Quesada-Ocampo;

E-mail address: lmquesad@ncsu.edu

*The $\boldsymbol{e}$-Xtra logo stands for "electronic extra" and indicates that one supplementary figure, one supplementary table, and one supplementary file are published online.

http://dx.doi.org/10.1094/PHYTO-10-15-0260-FI

(C) 2016 The American Phytopathological Society
(Cohen et al. 2014; Gascuel et al. 2015; Testen et al. 2013). Increasing diagnostic and airborne inoculum monitoring capabilities for downy mildew pathogens could aid in restricting movement of infected plant material (Djalali Farahani-Kofoet et al. 2012) and improving forecasting and alert systems that predict inoculum dispersal (Ojiambo et al. 2015).

Recent studies have developed PCR assays for detection of the downy mildew pathogens of cucurbits (Pseudoperonospora cubensis) (Summers et al. 2015), hop (Pseudoperonospora humuli) (Gent et al. 2009), basil (Peronospora belbahrii) (Djalali FarahaniKofoet et al. 2012), spinach (Peronospora effusa), and beet (Peronospora schachtii) (Klosterman et al. 2014) on seed or from air samples to develop alert systems based on primary inoculum levels. PCR primers and markers in these studies were developed from conserved regions such as the internal transcribed spacer (ITS) or mitochondrial genes, resulting in nonspecific amplification of closely related species (Gent et al. 2009; Klosterman et al. 2014). Such assays have limitations for monitoring inoculum in environmental samples since different downy mildew species may be present at the time of sampling due to production of susceptible crops in the same region (Gent et al. 2009; Klosterman et al. 2014). Disease alert systems based on airborne inoculum require species-specific diagnostic assays for timely initiation of disease control measures on a particular crop that is susceptible to its corresponding downy mildew pathogen (Gent et al. 2009; Klosterman et al. 2014).

Next-generation sequencing (NGS) offers the opportunity to generate the genomic resources required to identify species-specific markers through comparative genomics and develop diagnostic assays in downy mildew pathogens as has been done for bacterial plant pathogens (Lang et al. 2010). P. cubensis constitutes an interesting case study to test an approach for development of diagnostics that combines generation of limited genomic data with a candidate validation step to identify novel and robust molecular 
diagnostic tools for downy mildew pathogens. $P$. cubensis has an unusually broad host range for a downy mildew pathogen and it can infect diverse and economically important cucurbit crops such as cucumber, cantaloupe, watermelon, squash, and pumpkin, as well as wild cucurbit hosts (Holmes et al. 2015; Runge and Thines 2009; Wallace et al. 2014, 2015). The pathogen is difficult to control since it causes explosive epidemics, may travel long distances via airborne spores, there is no effective host resistance available, and fungicide resistance can quickly develop in pathogen populations (Holmes et al. 2015). Currently, the disease is controlled with intensive fungicide treatments that are initiated once an outbreak is reported in a state or region (Holmes et al. 2015); thus, accurate and timely identification of the pathogen is key for effective disease management. Within $P$. cubensis, there is population structure by host and also geographic region, the latter reflecting host availability in areas such as the southeastern United States (Holmes et al. 2015; Quesada-Ocampo et al. 2012). The closely related species $P$. humuli causes downy mildew on hop (Gent and Ocamb 2009), cannot be distinguished consistently from $P$. cubensis based on morphological characters or ITS sequence, and has an overlapping geographical range with $P$. cubensis in several regions (Gent et al. 2009; Mitchell et al. 2011). In this study we aimed to identify $P$. cubensis-specific diagnostic markers by using a comparative genomics strategy between $P$. cubensis and the closely related species, $P$. humuli.

\section{MATERIALS AND METHODS}

Sample preparation for sequencing and candidate validation. Isolates of $P$. cubensis and $P$. humuli used in this study for genome and transcriptome sequencing are listed in Table 1. Isolates were propagated on detached leaves to minimize contamination from other pathogens and insects and to obtain high quality RNA and DNA for sequencing. $P$. cubensis and $P$. humuli isolates were propagated on the host that they were originally isolated from. Detached leaves were placed upside down on moist sterile paper towels inside clear acrylic boxes, spray inoculated with a sporangial suspension of 1 to $3 \times 10^{4}$ sporangia/ml for each isolate, and incubated at $25^{\circ} \mathrm{C}$ with an $12 \mathrm{~h}$ light/dark cycle in a precision plant growth chamber (Thermo Fisher Scientific, Waltham, MA). Sporangia were dislodged from leaves using a Preval sprayer (Preval, Coal City, IL) with sterile water, collected into a tube, and pelleted by centrifugation. Sporangia intended for use in RNA extractions were then suspended in RNALater (Life Technologies,
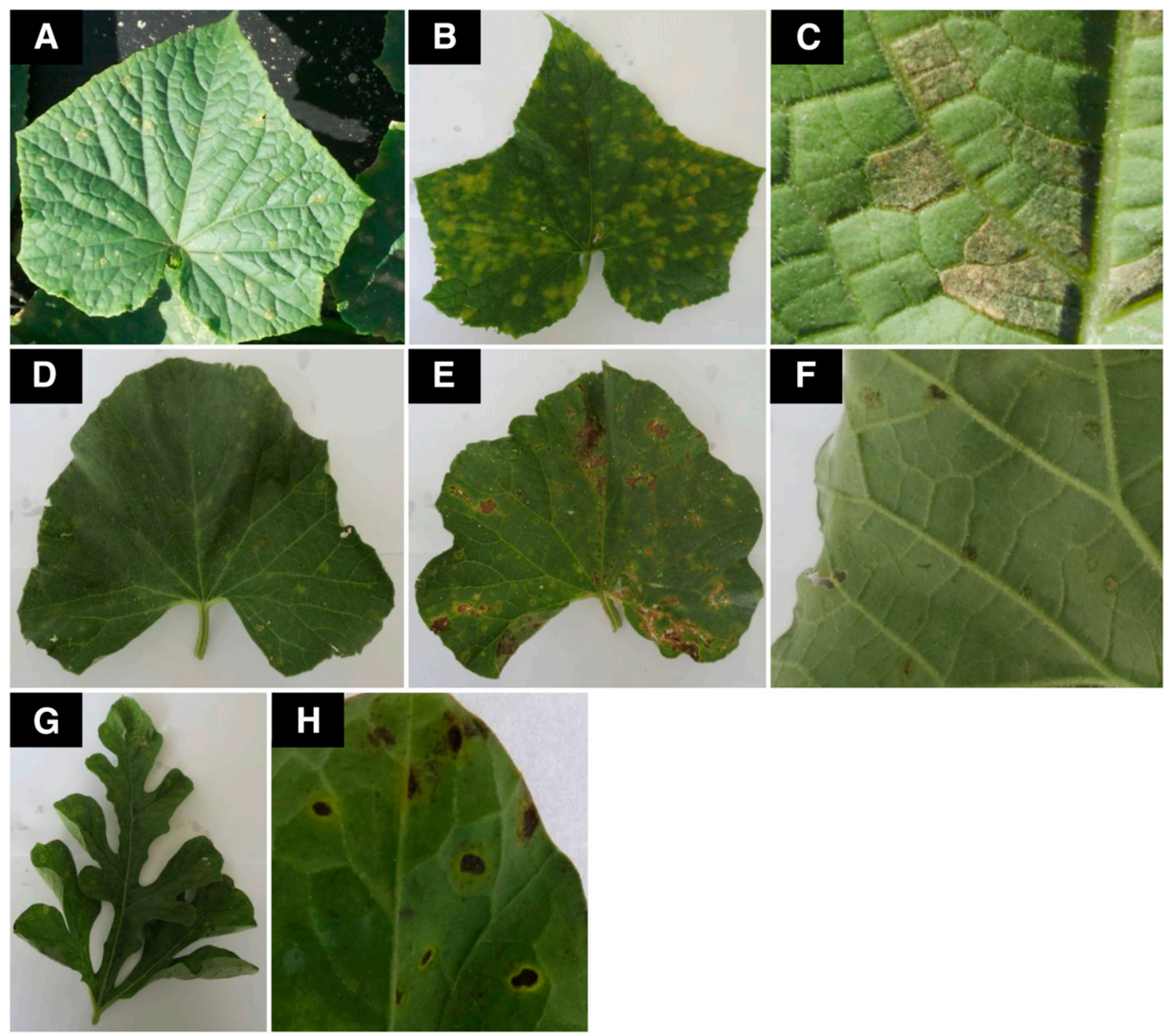

Fig. 1. Downy mildew symptoms in different cucurbits caused by Pseudoperonospora cubensis. A, Early infection ( $<30 \%$ severity) on a cucumber leaf; B, advanced infection with characteristic angular lesions delimited by leaf veins, and $\mathbf{C}$, profuse pathogen sporulation on the underside of the leaf. D, Early infection on a cantaloupe leaf; $\mathbf{E}$, advanced infection with irregular, necrotic lesions, and $\mathbf{F}$, little pathogen sporulation on the underside of the leaf. G, Infected watermelon leaf with rounded, necrotic lesions and $\mathbf{H}$, little pathogen sporulation on the underside of the leaf. 
Grand Island, NY) at a sporangial concentration of $1 \mathrm{mg} / \mu \mathrm{l}$, while sporangia for DNA extraction were suspended in sterile water. Additional samples used for the diagnostic candidate validation included infected lesions with sporulation or no sporulation collected from field samples (Table 2), mycelia from other oomycetes (Table 2), and uninfected plant tissue grown in the laboratory (Table 3). Samples were stored in microcentrifuge tubes in liquid nitrogen for long-term preservation.

RNA and DNA extraction, library preparation, and sequencing. In preparation for RNA and DNA extraction, $50 \mu \mathrm{l}$ of sporangial suspension from each isolate was collected in a microcentrifuge tube with $500 \mu \mathrm{m}$ glass beads (Sigma, St. Louis, $\mathrm{MO}$ ) and $1 \mathrm{mg}$ of polyvinyl polypyrrolidone (PVPP). Infected lesions, uninfected plant tissue, and other oomycete tissues were each collected into microcentrifuge tubes with three $2.3 \mathrm{~mm}$ Zircon beads (Biospec, Bartlesville, OK), $50 \mathrm{mg}$ of $500 \mu \mathrm{m}$ glass beads (Sigma), and $1 \mathrm{mg}$ of PVPP. All tissues for RNA and DNA extraction were lysed using an OMNI International BeadRuptor (OMNI International, Tulsa, OK). RNA was extracted using the Qiagen Plant RNeasy Kit (Qiagen, Valencia, CA) with an oncolumn DNAse digestion using the Qiagen DNAse Digest (Qiagen), both according to manufacturer's instructions. RNA was eluted with 30 to $100 \mu \mathrm{l}$ of DEPC-treated water and re-precipitated using 1/10 volume of $3 \mathrm{M}$ sodium acetate and two volumes of $96 \%$ ethanol, washed with $500 \mu \mathrm{l}$ of $80 \%$ ethanol and resuspended with 30 to $100 \mu \mathrm{l}$ of DEPC-treated water. DNA extractions were completed using $500 \mu \mathrm{l}$ of SDS extraction buffer (200 mM Tris-HCl, pH 8, $250 \mathrm{mM} \mathrm{NaCl}, 25 \mathrm{mM}$ EDTA, $0.5 \% \mathrm{SDS}$ ) followed by one $500-\mu \mathrm{l}$ phenol and two 500- $\mu$ l chloroform extractions. DNA was precipitated with 0.5 volume of $100 \%$ isopropanol, washed with $500 \mu \mathrm{l}$ of $80 \%$ ethanol, suspended in $100 \mu$ of sterile distilled water, and then reprecipitated with sodium acetate and ethanol as described above, and resuspended in sterile 30 to $100 \mu \mathrm{l}$ of distilled water. RNA samples for sequencing were quantified using the Qubit RNA HS assay (Life Technologies), DNA samples for sequencing using the Qubit DNA BR assay (Life Technologies), and DNA samples for the diagnostic screen were quantified using a Nanodrop 1000 (Thermo Fisher Scientific). Total RNA was checked for integrity and quality using the Agilent Bioanalyzer 2100 (Agilent Technologies, Santa Clara, CA). DNA quality assessment was based on gel electrophoresis on a $1 \%$ agarose gel containing ethidium bromide at $0.2 \mu \mathrm{g} / \mathrm{ml}$, followed by detection with a Bio-Rad Geldoc Imager using Quantity One software (Bio-Rad, Hercules, CA).

High quality total RNA and DNA were submitted to the Michigan State University Research Technology Support Facility (MSURTSF) for Illumina Truseq RNA (350-bp insert size) and DNA (500-bp insert size) library preparation (Illumina, San Diego, CA). RNA and DNA libraries were barcoded and multiplexed for 50-bp single-end RNA-seq and 100-bp paired-end DNA-seq, respectively. All samples were run on an Illumina HiSEquation 2500 (Illumina) and base calling and quality values were determined using the Illumina software as part of the service provided by the MSU-RTSF.

Identification of candidate diagnostic markers and primer design. RNA-seq and DNA-seq reads were analyzed for quality using FastQC (v. 0.10.1) (Andrews 2012). Cutadapt (v. 1.8.1) (Martin 2012) and FASTX-Toolkit (v. 0.0.13) (Hannon 2010) were used to remove adaptors and trim low quality sequences from the data set, respectively. Due to the obligate nature of $P$. cubensis and $P$. humuli, it is likely to find plant contamination in the RNA and DNA samples. Thus, to determine the level of plant contamination in the samples RNA-seq reads were aligned to the Cucumis sativus (cucumber) genome (Huang et al. 2009) using Bowtie2 short read aligner (v. 2.1.0) (Langmead et al. 2009). To identify diagnostic candidates, RNA-seq reads from $P$. cubensis and $P$. humuli were aligned to the $P$. cubensis draft genome (Savory et al. 2012a; Savory et al. 2012b) using Bowtie2 short read aligner (v. 2.1.0). The number of aligned reads in each exon of the $P$. cubensis draft genome was quantifed using htseq-count from HTSeq (v. 0.6.1) (Anders et al. 2015) with default parameters. Exons in the P. cubensis draft genome with at least two mapped reads from $P$. cubensis RNA-seq samples and less than two mapped reads from $P$. humuli RNA-seq samples were identified and selected using Perl and Bash programming. Exons present in all $P$. cubensis RNA-seq samples $(\geq 2$ mapped reads) but absent in all $P$. humuli RNA-seq samples $(<2$ mapped reads) were matched to specific genes using the $P$. cubensis draft genome GFF3 file coordinates (Savory et al. 2012a). To further reduce the number of diagnostic candidates to validate with PCR, DNA-seq data were aligned in single end mode to the $P$. cubensis draft genome using Bowtie2 (v. 2.1.0) (Langmead et al. 2009) and mapped reads were quantified using htseq-count from HTSeq (v. 0.6.1) (Anders et al. 2015). Candidates were eliminated if two or more DNA-seq reads from $P$. humuli were present in the candidate exon. Approximately $50 \%$ of the remaining candidates were validated by PCR against a larger selection of lesions infected with P. cubensis or P. humuli, other oomycete isolates (Table 2), and host plants (Table 3) to eliminate candidates that occur infrequently, or that are present in more distantly related oomycetes, or in the host (Fig. 2). To determine if candidate diagnostic markers were in putative single copy genes, a self-BLASTP (Altschul et al. 1990) analysis of the $P$. cubensis predicted proteome (Savory et al. 2012a) using an E-value cutoff of $1 \mathrm{e}^{-10}$ was performed. Candidates were considered single copy if protein sequences had only one match to the proteome. Since several candidate diagnostic markers were annotated as genes of unknown function, a BLASTX analysis against Phytophthora infestans, Phytophthora capsici, and Hyaloperonospera arabidopsis proteins was performed to improve gene functional annotation. The collection of protein sequences were downloaded from the National Center for Biotechnology Information (NCBI) on 3 June 2015 and an E-value cutoff of $1 \mathrm{e}^{-05}$

TABLE 1. Pseudoperonospora cubensis and P. humuli isolates used for Illumina 50-bp single-end RNAseq and 100-bp paired-end DNAseq

\begin{tabular}{|c|c|c|c|c|c|}
\hline Pathogen species & Isolate & Host & Location & Year collected & Source \\
\hline P. cubensis & CA08A1 & Cucumis sativus (cucumber) & California & 2008 & Ojiambo \\
\hline P. cubensis & SC1982 & Cucumis melo (cantaloupe) & South Carolina & 1982 & Ojiambo \\
\hline P. cubensis & NC2013C3 & Cucurbita maxima (pumpkin) & North Carolina & 2013 & Ojiambo \\
\hline P. cubensis & SC2013F2 & Cucurbita pepo (acorn squash) & South Carolina & 2013 & Ojiambo \\
\hline P. cubensis & NCA11 & Cucumber & North Carolina & 2012 & Ojiambo \\
\hline P. cubensis & SCD3 & Cucurbita moschata (butternut squash) & South Carolina & 2012 & Ojiambo \\
\hline P. cubensis & NCWAY2-1 & Cucumber & North Carolina & 2013 & Quesada \\
\hline P. humuli & NY482CA & Humulus lupulus (hop) & New York & 2011 & Gent \\
\hline P. humuli & JP490-5 & Humulus japonicus (Japanese hop) & Aomori, Japan & 2012 & Gent \\
\hline P. humuli & JP490 & Japanese hop & Aomori, Japan & 2012 & Gent \\
\hline P. humuli & JP498SA & Japanese hop & Ehoro, Japan & 2012 & Gent \\
\hline P. humuli & OR501BA & Hop & Oregon & 2013 & Gent \\
\hline P. humuli & OR502AA ${ }^{\mathrm{a}}$ & Hop & Oregon & 2013 & Gent \\
\hline P. humuli & VT503A3 & Hop & Virginia & 2013 & Gent \\
\hline P. humuli & WI510-1 & Hop & Wisconsin & 2013 & Gent \\
\hline
\end{tabular}

a Isolate also used for DNAseq. 
was used to define homologous sequences. To further determine that candidates were specific to $P$. cubensis, gene sequences of the diagnostic candidates were used to perform a BLASTN (Altschul et al. 1990) search against the NCBI nucleotide collection (nr/nt) database using default parameters to retain candidates with no significant sequence similarity to other organisms for laboratory validation.

Raw reads were deposited in the Sequence Read Archive at NCBI under accession number SRP063950.

Validation of diagnostic candidates. Fasta sequences of genes containing candidate diagnostic exons and the 200-bp region flanking each gene were selected using extracseq from EMBOSS (v. 6.5.7). Primers were designed for $P$. cubensis diagnostic candidates selected for validation within 200-bp $5^{\prime}$ and $3^{\prime}$ end of the candidate gene using CLC Genomics Workbench (CLCbio, Boston,
MA) and IDT Oligo Analyzer (Integrated DNA Technologies, Coralville, IA). The $P$. cubensis draft genome and the RNA-seq and DNA-seq read alignments were imported into RNA-seq tools of the CLC Genomics Workbench to identify primers flanking diagnostic candidates. Primers were designed to produce product sizes between 200 and 1,200 bp with an annealing temperature of 55 to $57^{\circ} \mathrm{C}$, and were ordered through IDT (Integrated DNA Technologies). The PCR reactions, completed according to manufacturer's guidelines, contained $1 \times$ Promega GoTaq Green Master Mix (Promega, Durham, NC), $10 \mu \mathrm{M}$ of forward and reverse primers, and $10 \mu \mathrm{M}$ DNA, and were amplified with a program starting with $94^{\circ} \mathrm{C}$ for 3 min, followed by 35 cycles of $94^{\circ} \mathrm{C}$ for $30 \mathrm{~s}$, $55^{\circ} \mathrm{C}$ for $30 \mathrm{~s}, 72^{\circ} \mathrm{C}$ for $30 \mathrm{~s}$, with a final elongation step of $72^{\circ} \mathrm{C}$ for $5 \mathrm{~min}$. Products were analyzed by gel electrophoresis on a $2 \%$ agarose gel containing ethidium bromide at $0.2 \mu \mathrm{g} / \mathrm{ml}$, followed by

TABLE 2. Peronospora belbahrii, Pseudoperonospora cubensis, Pseudoperonospora humuli, Plasmopara obducens, Phytophthora capsici, and Phytophthora infestans isolates used for validation of $P$. cubensis-specific diagnostic candidates

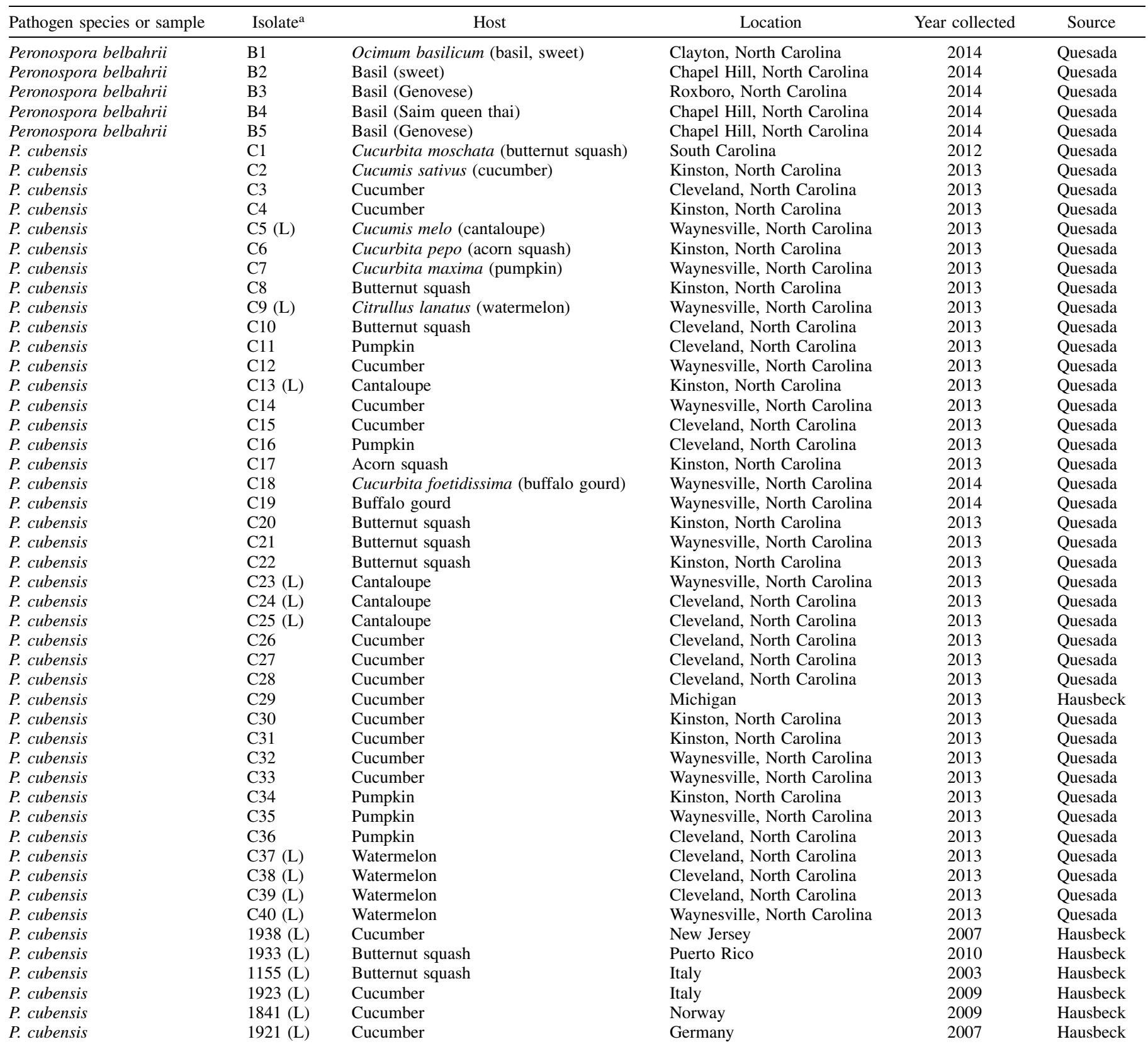

(continued on next page)

a (L) indicates infected lesion sample with low or no sporulation; (M) indicates mycelia sample; and other samples are lesions. 
detection with a Geldoc Imager using Quantity One software (Bio$\mathrm{Rad})$. Product sizes were estimated by comparison with the Life Technologies 100-bp DNA ladder. Diagnostic candidates with product sizes similar in $P$. cubensis and $P$. humuli samples, as well as any that were amplified in any of the plant hosts or other oomycetes screened were eliminated. Candidates remaining after at least three validation iterations were considered highly specific diagnostic molecular markers for $P$. cubensis (Supplementary File S1).

\section{RESULTS}

The approach used in our study successfully identified seven diagnostic markers for $P$. cubensis by using comparative genomics with the closely related species $P$. humuli, a previously published P. cubensis draft genome assembly (Savory et al. 2012b), minimal additional genomic data, and validation of diagnostic candidates with diverse samples (Fig. 2).

Identification of candidate diagnostic markers. A range of 11,942,671 to 29,304,711 million of RNA-seq and 36,599,100 million of DNA-seq reads were obtained and checked for quality (Table 4). In general, only 0.21 to $0.49 \%$ of reads were removed from RNA-seq samples and 40\% from DNA-seq samples due to low quality and plant contamination (Table 4). High quality RNAseq and DNA-seq reads aligned to the $P$. cubensis draft genome confirmed that the majority of sequences were from the pathogens (Table 4). The highest and lowest percentages of total aligned RNA-seq reads for $P$. cubensis samples to the $P$. cubensis genome were 95 and $79.9 \%$, respectively. For $P$. humuli samples, the highest and lowest percentage of total aligned RNA-seq reads to the $P$. cubensis draft genome was 92.3 and $66.9 \%$, respectively, and 97.5 and $96 \%$ was the highest and lowest total alignment percentage for DNA-seq

TABLE 2. (continued from preceding page)

\begin{tabular}{|c|c|c|c|c|c|}
\hline Pathogen species or sample & Isolate $^{\mathrm{a}}$ & Host & Location & Year collected & Source \\
\hline P. cubensis & $1924(\mathrm{~L})$ & Cucumber & Netherlands & 2001 & Hausbeck \\
\hline P. cubensis & 1925 (L) & Cucumber & Spain & 2001 & Hausbeck \\
\hline P. cubensis & $1927(\mathrm{~L})$ & Butternut squash & Spain & 2003 & Hausbeck \\
\hline P. humuli & $\mathrm{H} 1$ & Humulus lupulus (hop) & Mills River, North Carolina & 2014 & Quesada \\
\hline P. humuli & $\mathrm{H} 2$ & Hop & Mills River, North Carolina & 2014 & Quesada \\
\hline P. humuli & H3 & Hop & Mills River, North Carolina & 2014 & Quesada \\
\hline P. humuli & $\mathrm{H} 4$ & Hop & Oregon & 2012 & Gent \\
\hline P. humuli & H5 & Hop & New York & 2011 & Gent \\
\hline P. humuli & H6 & Hop & New York & 2011 & Gent \\
\hline P. humuli & $\mathrm{H} 7$ & Hop & Virginia & 2013 & Gent \\
\hline P. humuli & $\mathrm{H} 8$ & Hop & Oregon & 2013 & Gent \\
\hline P. humuli & H9 & Hop & Oregon & 2013 & Gent \\
\hline P. humuli & $\mathrm{H} 10$ & Hop & Japan & 2012 & Gent \\
\hline P. humuli & H11 & Hop & Japan & 2012 & Gent \\
\hline P. humuli & $\mathrm{H} 12$ & Hop & Mills River, North Carolina & 2014 & Quesada \\
\hline P. humuli & H13 & Hop & Oregon & 2006 & Gent \\
\hline P. humuli & H14 & Hop & Oregon & 2008 & Gent \\
\hline P. humuli & H15 & Hop & Washington & 2008 & Gent \\
\hline P. humuli & H16 & Hop & Oregon & 2008 & Gent \\
\hline P. humuli & H17 & Hop & New York & 2013 & Gent \\
\hline P. humuli & H18 & Hop & New York & 2013 & Gent \\
\hline P. humuli & H19 & Hop & Virginia & 2013 & Gent \\
\hline P. humuli & $\mathrm{H} 20$ & Hop & Czech Republic & 2012 & Gent \\
\hline P. humuli & $\mathrm{H} 21$ & Hop & New York & 2011 & Gent \\
\hline P. humuli & $\mathrm{H} 22$ & Hop & Oregon & 2011 & Gent \\
\hline P. humuli & $\mathrm{H} 23$ & Hop & Mills River, North Carolina & 2014 & Quesada \\
\hline P. humuli & $\mathrm{H} 24$ & Hop & Mills River, North Carolina & 2014 & Quesada \\
\hline P. humuli & $\mathrm{H} 25$ & Hop & New York & 2011 & Gent \\
\hline P. humuli & $\mathrm{H} 26$ & Hop & Oregon & 2013 & Gent \\
\hline P. humuli & $\mathrm{H} 27$ & Hop & Aomori, Japan & 2012 & Gent \\
\hline P. humuli & $\mathrm{H} 28$ & Hop & Oregon & 2013 & Gent \\
\hline P. humuli & $\mathrm{H} 29$ & Hop & Oregon & 2007 & Gent \\
\hline P. humuli & H30 & Hop & Oregon & 2008 & Gent \\
\hline P. humuli & H31 & Hop & Washington & 2008 & Gent \\
\hline P. humuli & H32 & Hop & New York & 2013 & Gent \\
\hline P. humuli & H33 & Hop & Washington & 2006 & Gent \\
\hline P. humuli & H34 & Hop & Oregon & 2008 & Gent \\
\hline Plasmopara obducens & I1 & Impatiens walleriana (impatiens) & Michigan & 2014 & Hausbeck \\
\hline Plasmopara obducens & $\mathrm{I} 2$ & Impatiens & Michigan & 2014 & Hausbeck \\
\hline Plasmopara obducens & $\mathrm{I} 3$ & Impatiens & Michigan & 2014 & Hausbeck \\
\hline Phytophthora capsici & P1 (M) & Watermelon & North Carolina & 2014 & Quesada \\
\hline Phytophthora capsici & P2 (M) & Capsicum anпиит (pepper) & NA & NA & Ristaino \\
\hline Phytophthora capsici & P3 (M) & Cucurbita pepo (zucchini) & South Carolina & NA & Ristaino \\
\hline Phytophthora capsici & P4 (M) & Watermelon & South Carolina & NA & Ristaino \\
\hline Phytophthora capsici & P5 (M) & Pepper & Michigan & NA & Hausbeck \\
\hline Phytophthora capsici & P6 (M) & Pumpkin & Michigan & NA & Hausbeck \\
\hline Phytophthora infestans & Pi1 (M) & Solanum tuberosum (potato) & Pennsylvania & 2009 & Ristaino \\
\hline Phytophthora infestans & $\mathrm{Pi} 2(\mathrm{M})$ & Potato & North Carolina & 1994 & Ristaino \\
\hline Phytophthora infestans & Pi3 (M) & Solanum lycopersicum (tomato) & California & 1998 & Ristaino \\
\hline Phytophthora infestans & $\mathrm{Pi} 4$ (M) & Tomato & Pennsylvania & 2009 & Ristaino \\
\hline Phytophthora infestans & Pi5 (M) & Tomato & North Carolina & 2009 & Ristaino \\
\hline Phytophthora infestans & Pi6 (M) & Tomato & Virginia & 2009 & Ristaino \\
\hline Phytophthora infestans & $\mathrm{Pi} 7$ (M) & Potato & North Dakota & 2010 & Ristaino \\
\hline Phytophthora infestans & Pi8 (M) & Potato & North Dakota & 2009 & Ristaino \\
\hline
\end{tabular}


reads. A small percentage of RNA-seq reads of $P$. cubensis ( 0.5 to $6.7 \%$ ) and $P$. humuli ( 0.5 to $7.5 \%$ ) isolates aligned to the $C$. sativus reference genome. Similarly, a low percentage (12 to $13 \%$ ) of DNA-seq reads from a single $P$. humuli isolate aligned to the $C$. sativus reference genome (Table 4). The total $P$. cubensis and $P$. humuli RNA-seq and DNA-seq reads aligned to the $P$. cubensis draft genome and the $C$. sativus reference genome for each sample were sorted in uniquely mapped reads and multiple mapped reads to further assess read quality. A range of 92 to $96 \%$ of uniquely mapped reads was observed, confirming the good quality of the RNA-seq reads (Supplementary Fig. S1).

An analysis of exon expression performed on mapped RNA-seq reads indicated that 2,696 $P$. cubensis exons were expressed in all $P$. cubensis isolates, 649 P. cubensis exons were expressed in all $P$. humuli isolates, and 19,275 P. cubensis exons were expressed in

TABLE 3. Plant hosts used for validation of Pseudoperonospora cubensisspecific diagnostic candidates

\begin{tabular}{lll}
\hline Host species & Common name & \multicolumn{1}{c}{ Cultivar } \\
\hline Cucumis sativus & Cucumber & Straight 8 \\
Cucumis melo & Cantaloupe & Hale's Best Jumbo \\
Cucurbita pepo & Acorn squash & Table Queen \\
Cucurbita maxima & Pumpkin & Big Max \\
Cucurbita moschata & Butternut squash & Waltham Butternut \\
Citrullus lanatus & Watermelon & Mickey Lee \\
Ocimum basilicum & Basil & Sweet Basil \\
Humulus lupulus & Hop & Pacific Gem \\
\hline
\end{tabular}

all sequenced isolates of both species. Moreover, 762 and 1,134 $P$. cubensis exons were found to be not expressed in any $P$. cubensis and $P$. humuli isolates, respectively, and 13,612 P. cubensis exons were not expressed in isolates of either species. A total of 70 $P$. cubensis exons were identified from 51 genes that were expressed in all $P$. cubensis isolates and not in any $P$. humuli isolates sequenced (Fig. 3, Supplementary Table S1). Self-BLASTP analyses revealed that 6 of the 51 candidate diagnostic genes were putative single copy genes. Of the 51 identified genes, 29 were annotated as genes or proteins of unknown function. The remaining 22 genes had functional annotations related to virulence (elicitins, elicitors, NPP1 and CRN proteins) and signaling, among others. BLAST searches performed against a protein database from Phytophthora infestans, Phytophthora capsici, and Hyaloperonospora arabidopsidis allowed annotation of three more genes. These three genes were putatively identified as involved in functions related to virulence (c27478.0e0), glycolysis (c30239.0e0), and chromatin remodeling (c2555.4e5). Candidate c2163.6e 5 had 78\% identity (38\% query cover and $5 \mathrm{e}^{-87} \mathrm{E}$ value) with a Phytophthora sojae hypothetical protein (XM_009528096.1), c31609.0e0 had 93\% identity (17\% query cover and $2 \mathrm{e}^{-06} \mathrm{E}$ value) with an Aphanomyces invadans protein kinase (XM_008871021.1), and c6944.1e0-1 had 89\% identity (24\% query cover and $8 \mathrm{e}^{-65} \mathrm{E}$ value) with a Phytophthora parasitica hypothetical protein (XM_008912304.1).

Validation of diagnostic candidates. An additional filtering step using HTSeq and DNA-seq data from a single $P$. humuli isolate allowed us to eliminate 29 P. cubensis exons in 21 genes that were not present in the RNA-seq data of $P$. humuli but were present at the
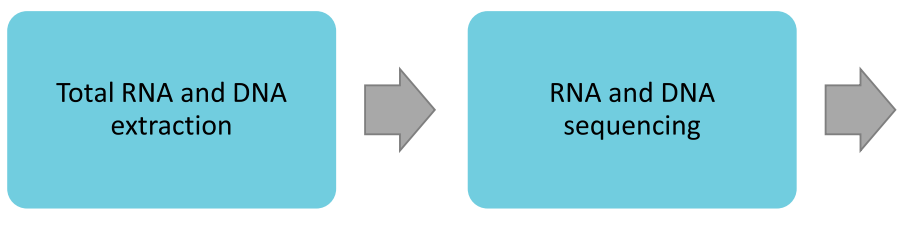

Sequence quality checking and cleaning

(FASTQC, Cutadapt \& FASTX toolkit)
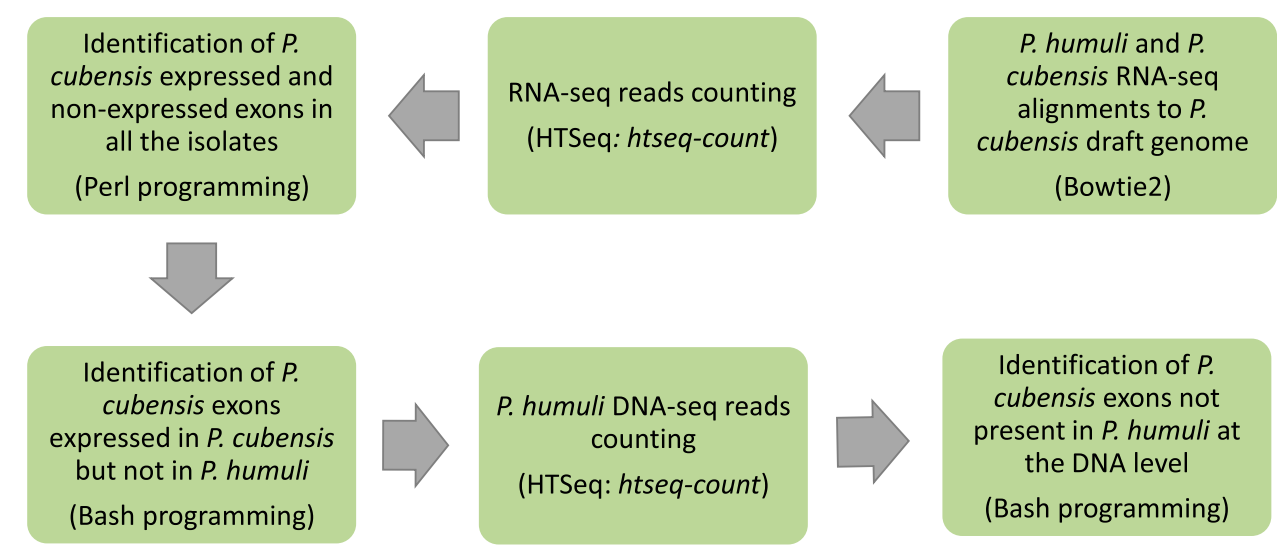

Identification of $P$.

cubensis exons not present in $P$. humuli at the DNA level

(Bash programming)
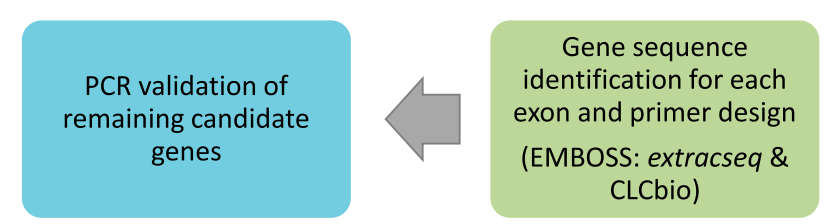

Fig. 2. Flow diagram describing our approach for identifying candidate diagnostic markers for Pseudoperonospora cubensis. 
DNA level. Of the remaining 30 genes determined to contain 41 exons unique to $P$. cubensis after bioinformatics analyses, a subset of 16 genes containing 26 exons ( $\sim 50 \%$ of candidates) were chosen for PCR validation with 96 diverse isolates (Table 2). An initial screening with 15 P. cubensis and $9 P$. humuli samples eliminated 15 candidate exons in 8 genes that had a product in $P$. humuli samples indistinguishable in size from the PCR product obtained in $P$. cubensis samples. The final screening for the remaining 11 exons in 8 genes included $40 P$. cubensis, $34 P$. humuli, 5 Peronospora belbahrii, 3 Plasmopara obducens, 6 Phytophthora capsici, and 8 Phytophthora infestans samples or isolates (Table 2). Eight plant hosts was also included in the validation due to the obligate nature of $P$. cubensis and comprised cucumber, cantaloupe, butternut squash, acorn squash, pumpkin, watermelon, basil, and hop (Table 3). This final screening eliminated 1 exon in 1 gene that had a product in Plasmopara obducens samples indistinguishable in size from the PCR product obtained in P. cubensis samples. No other candidates presented amplification of a product in other samples that could not be distinguished from $P$. cubensis.

These remaining 10 exons in 7 genes (c10851.1e0, c2555.2e1, c2555.3e7, c3155.4e9, c52.12e13, c572.6e19, and c2183.6e2) are considered highly specific diagnostic molecular markers for
P. cubensis that can be used to distinguish it from its sister species P. humuli (Table 5, Fig. 4). Two (c2555.2e1 and c2555.3e7) of these genes were found to be putative single copy genes through selfBLASTP analyses (Table 5). PCR assays with the designed primers and gel electrophoresis of the seven final diagnostic candidates revealed that three candidates (c255.2e1, c2555.3e7, and c10851.1e0) did not produce a PCR product in any $P$. humuli samples tested, while four candidates (c52.12e13, c572.6e19, c2183.6e2, and c3155.4e9) produced a PCR product of different size in some or all of the $P$. humuli samples tested. All diagnostic candidates successfully detected $P$. cubensis in hosts such as watermelon, cantaloupe, and buffalo gourd that typically have lower pathogen sporulation (Table 2, Fig. 5). Interestingly, one diagnostic candidate (c2555.3e7) with unknown function had polymorphism among $P$. cubensis samples tested depending on the host. Samples from infected watermelon, pumpkin, and butternut squash had a larger PCR product than those from cucumber, cantaloupe, and buffalo gourd.

\section{DISCUSSION}

NGS allows for development of sequence-based, cultureindependent diagnostics of pathogens (Pallen et al. 2010). A recent

TABLE 4. Summary of quality control analysis for Pseudoperonospora cubensis and P. humuli samples used for Illumina 50-bp single-end (SE) RNAseq and 100-bp paired-end (PE) DNAseq

\begin{tabular}{|c|c|c|c|c|c|c|c|}
\hline Pathogen species & Isolate & Molecule & $\begin{array}{l}\text { Sequencing } \\
\text { mode }\end{array}$ & $\begin{array}{l}\text { Number of } \\
\text { total reads }\end{array}$ & $\begin{array}{l}\text { Number of high } \\
\text { quality reads }\end{array}$ & $\begin{array}{l}\text { Reads mapped to } \\
\text { P. cubensis }(\%)\end{array}$ & $\begin{array}{c}\text { Reads mapped to } \\
\text { Cucumis sativus }(\%)\end{array}$ \\
\hline P. cubensis & CA08A1 & RNA & SE & $23,691,206$ & $23,576,348$ & 92.96 & 0.49 \\
\hline P. cubensis & SC1982 & RNA & SE & $22,117,725$ & $22,049,442$ & 93.6 & 6.24 \\
\hline P. cubensis & NC2013C3 & RNA & SE & $28,035,867$ & $27,888,243$ & 87.98 & 0.62 \\
\hline P. cubensis & SC2013F2 & RNA & SE & $16,956,357$ & $16,886,934$ & 79.89 & 5.8 \\
\hline P. cubensis & NCA11 & RNA & SE & $28,101,878$ & $27,962,061$ & 88.33 & 0.62 \\
\hline P. cubensis & SCD3 & RNA & SE & $29,304,711$ & $29,218,196$ & 95.08 & 4.26 \\
\hline P. cubensis & NCWAY2-1 & RNA & SE & $21,038,800$ & $20,974,369$ & 94.58 & 6.7 \\
\hline P. humuli & NY482CA & RNA & SE & $15,906,769$ & $15,860,532$ & 91.45 & 7.54 \\
\hline P. humuli & JP490-5 & RNA & SE & $20,211,068$ & $20,149,698$ & 92.12 & 4.58 \\
\hline P. humuli & JP490 & RNA & SE & $11,942,671$ & $11,913,949$ & 66.91 & 6.45 \\
\hline P. humuli & JP498SA & RNA & SE & $26,977,356$ & $26,866,989$ & 90.01 & 0.54 \\
\hline P. humuli & OR501BA & RNA & SE & $14,429,953$ & $14,399,612$ & 88.53 & 5.55 \\
\hline P. humuli & OR502AA ${ }^{a}$ & RNA & SE & $26,193,148$ & $26,086,672$ & 92.28 & 0.51 \\
\hline P. humuli & VT503A3 & RNA & SE & $14,576,962$ & $14,543,704$ & 91.75 & 5.69 \\
\hline P. humuli & WI510-1 & RNA & SE & $29,264,282$ & $29,150,378$ & 88.78 & 0.68 \\
\hline P. humuli & OR502AA_R1 ${ }^{\mathrm{a}}$ & DNA & $\mathrm{PE}$ & $36,599,100$ & $21,778,230$ & 97.46 & 12.02 \\
\hline P. humuli & OR502AA_R2 ${ }^{\mathrm{a}}$ & DNA & PE & $36,599,100$ & $21,778,230$ & 95.99 & 13.2 \\
\hline
\end{tabular}

${ }^{\mathrm{a}}$ Isolate also used for DNAseq paired-end sequencing but reads were aligned to the P. cubensis genome as single-end reads (R1 and R2).

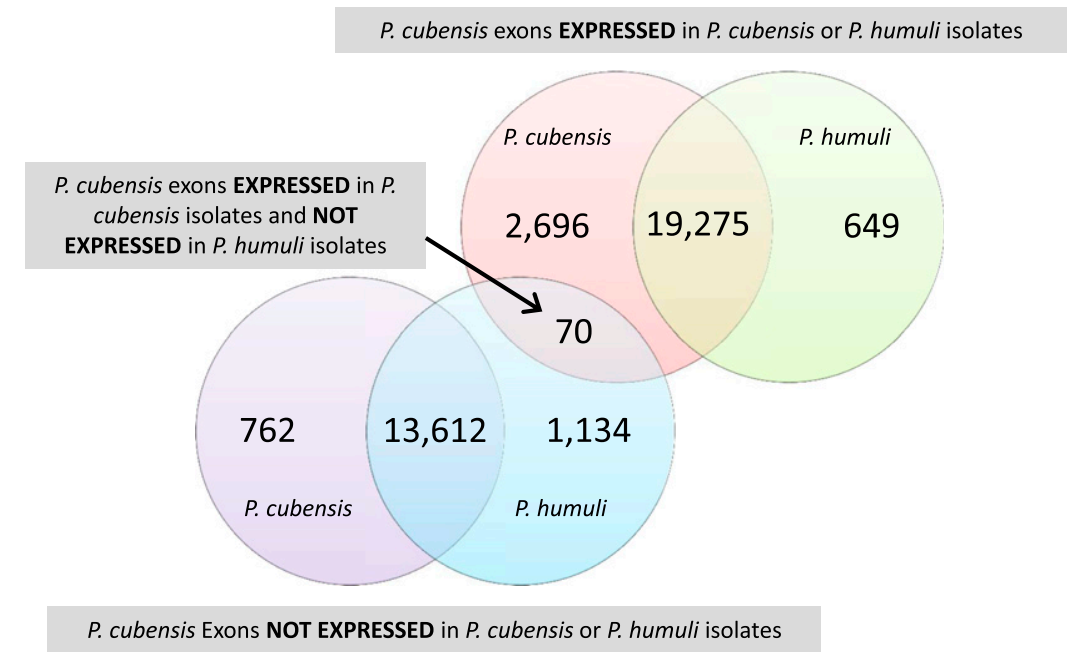

Fig. 3. Venn diagram describing results from HTSeq analysis. The number of expressed and not-expressed Pseudoperonospora cubensis exons in P. cubensis and $P$. humuli isolates sequenced are shown in the Venn diagram. 
study used genomics approaches to develop diagnostics for obligate pathogens of humans such as Parachlamydia acanthamoebae (Greub et al. 2009). In that study, a draft genome sequence of the emergent pathogen Parachlamydia acanthamoebae was obtained and used in combination with proteomics to identify immunogenic proteins and develop a serological diagnostic assay (Greub et al. 2009). However, there have been few examples of genomicsenabled diagnostics development for plant pathogens (De Boer and

TABLE 5. Candidate code, gene identifier, gene functional annotation, primers, and expected product sizes for final Pseudoperonospora cubensis-specific diagnostic candidates identified in this study

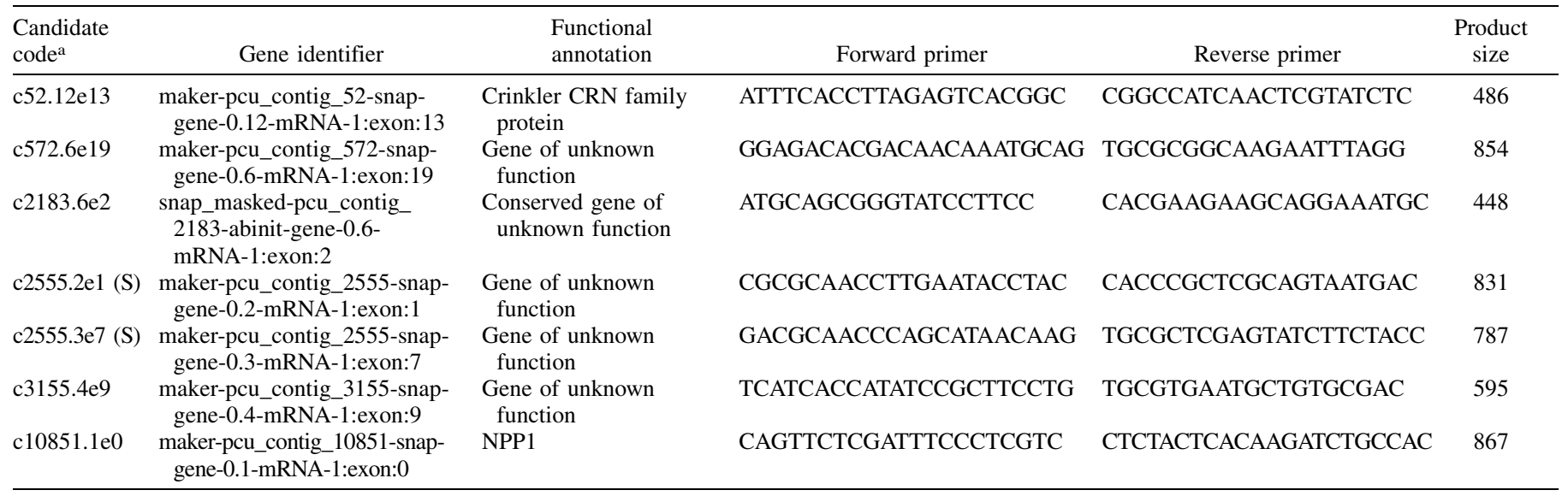

a (S) indicates putative single-copy gene according to self-BLASTP analyses.

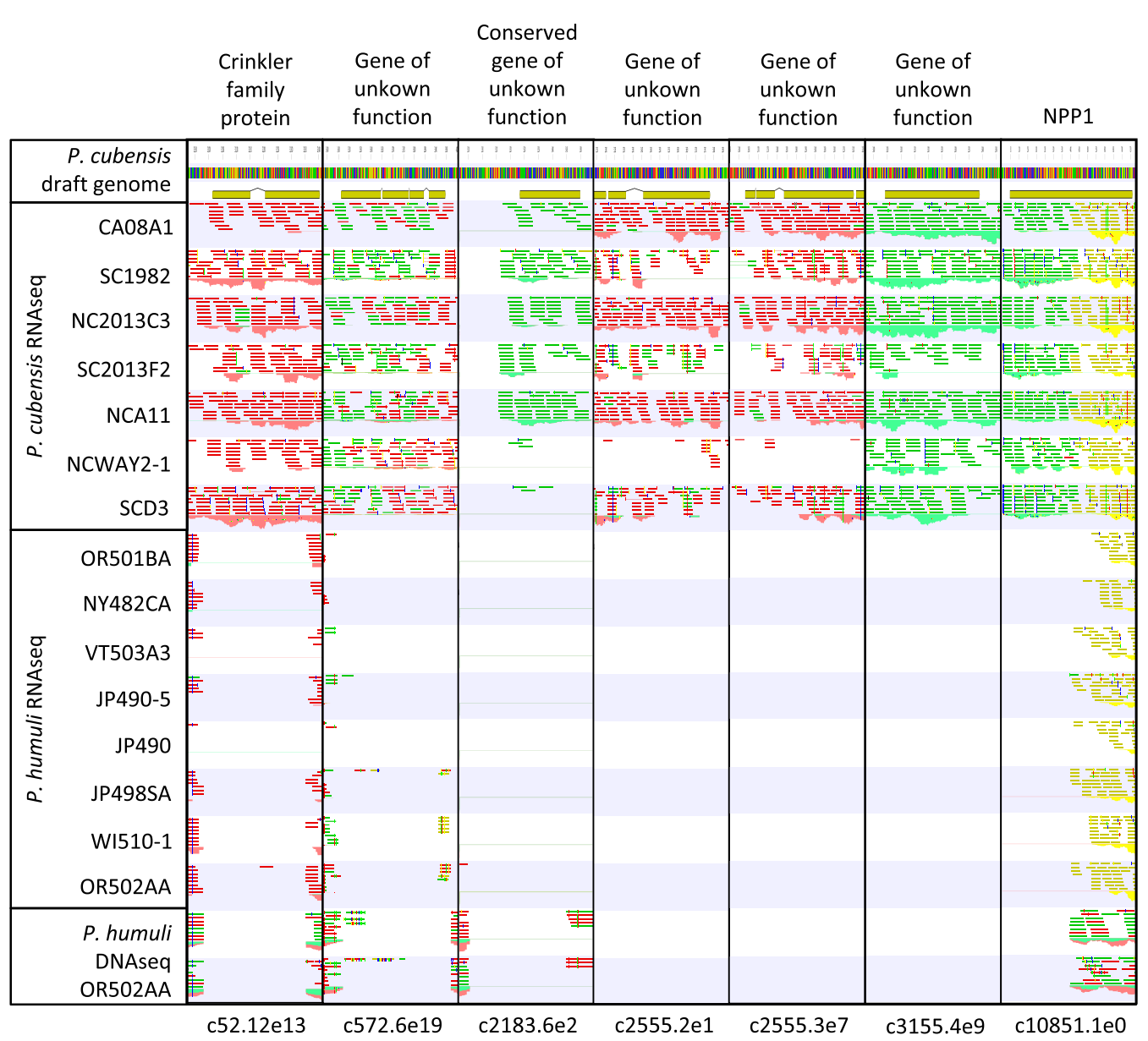

Fig. 4. Using next generation sequencing to identify species-specific regions in Pseudoperonospora cubensis utilizing comparative genomics with the closely related species $P$. humuli. Seven species-specific regions (c52.12e13, c572.6e19, c2183.6e2, c2555.2e1, c2555.3e7, c3155.4e9, and c10851.1e0) are shown in the figure as columns with the gene functional annotation above each column and the candidate diagnostic code bellow each column. The $P$. cubensis genome panel shows predicted genes in the $P$. cubensis genome that are absent or have missing exons in the $P$. humuli genome. RNA-seq was performed in a diverse panel of $P$. cubensis (CA08A1, SC1982, NC2013C3, SC2013F2, NCA11, NCWAY2-1, and SCD3) and P. humuli (OR501BA, NY482CA, VT503A3, JP490-5, JP498SA, WI510-1, and OR502AA) isolates to detect transcripts always present in $P$. cubensis but not present in $P$. humuli by mapping reads to the $P$. cubensis genome using HTSeq. To confirm the absence of the exon or gene at the DNA level in P. humuli and develop a PCR-based assay, DNA-seq was performed on P. humuli (OR502AA). Primers were designed flaking each gene to detect a size difference in PCR products between $P$. cubensis and $P$. humuli due to the absence of exons or genes in P. humuli. This figure was generated using the CLC Genomics Workbench (CLCbio, Boston, MA). 
Lopez 2012; Studholme et al. 2011), and most of these studies have been applied to either bacterial (Lang et al. 2010) or viral pathogens (Adams et al. 2009; Studholme et al. 2011). In this study we used a comparative genomics strategy to develop species-specific molecular diagnostics for the obligate oomycete $P$. cubensis, a devastating downy mildew pathogen of cucurbit crops (Savory et al. 2011).

A draft $P$. cubensis genome was available for this study; however, this genome is not of finished quality (N50 contig size of $4.0 \mathrm{kbp}$ )
(Savory et al. 2012a, b). Nonetheless, our study highlights the usefulness of genomic data even in unfinished format for marker development, especially for obligate pathogens where genomic resources are scarce and obtaining adequate amounts of DNA for laboratory testing may be difficult (Baxter et al. 2010; Links et al. 2011). The RNA-seq data allowed us to identify diagnostic candidates with differential expression between $P$. cubensis and $P$. humuli, but conserved within each species, and thus, robust across isolates

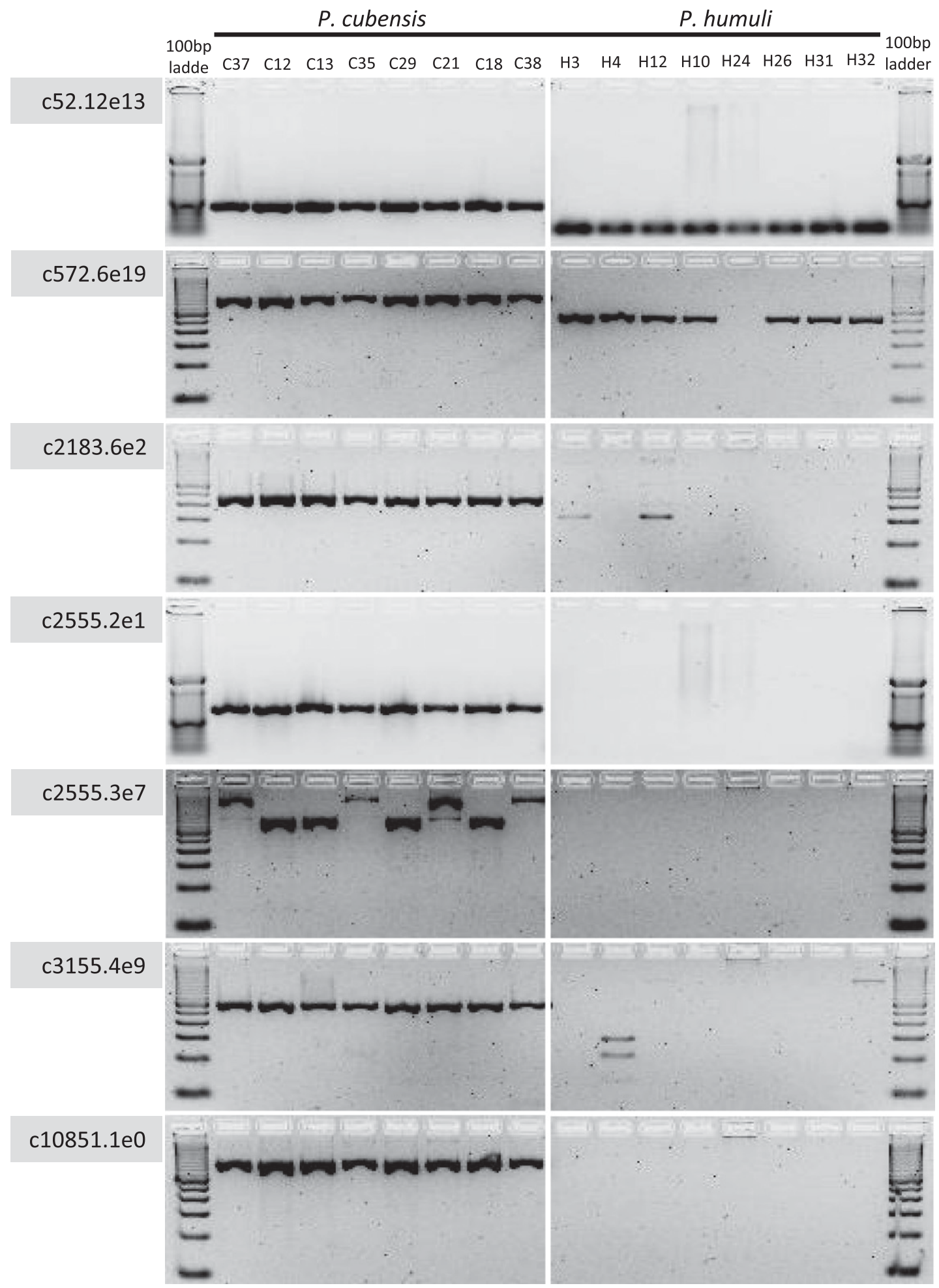

Fig. 5. Gel electrophoresis images showing seven Pseudoperonospora cubensis diagnostic candidate PCR products (c52.12e13, c572.6e19, c2183.6e2, c2555.2e1, c2555.3e7, c3155.4e9, and c10851.1e0) for diverse cucurbit downy mildew (C37, C12, C13, C35, C29, C21, C18, and C38) and hop downy mildew samples (H3, H4, H12, H10, H24, H26, H31, and H32). See Table 2 for sample information and Table 5 for primer information. Diagnostic candidate codes corresponding to each gel are indicated on the left side of each gel image. 
of these two frequently indistinguishable pathogens. The DNA-seq data allowed confirmation of presence or absence of an exon or a gene at the DNA level in $P$. humuli, since no genomic data are available for this pathogen. Prior knowledge of the genetic structure of P. cubensis and P. humuli (Mitchell et al. 2011; Quesada-Ocampo et al. 2012) informed our selection of diverse samples for sequencing and likely improved the efficient elimination of unsuitable candidates and increased validation success. The close relatedness between $P$. cubensis and $P$. humuli allowed for rapid identification of lineagespecific regions in $P$. cubensis that can be used for diagnostics, highlighting the importance of resolving phylogenetic relationships for development of robust diagnostics (Choi et al. 2005; Mitchell et al. 2011). Interestingly, several of the candidates identified had no significant sequence similarity to other organisms or informative functional annotation, while other candidates had gene functions related to stress (virulence), as has been observed for lineage-specific genes in plants (Campbell et al. 2007; Lin et al. 2010).

Since the diagnostic candidates were selected based on absence of an exon or a complete gene in $P$. humuli, diagnostic assays can be implemented as conventional PCR-based diagnostics that detect presence of product, product size differences, and or potentially with serological assays. In this study, we pursued validation of diagnostic candidates through PCR methods since such assays can be readily adopted by Plant Disease Clinics as well as extension personnel, while serological methods frequently require adoption and commercialization (De Boer and Lopez 2012). Nonetheless, since some of the diagnostic candidates identified in this study are present in $P$. cubensis but completely absent in P. humuli at the DNA level and potentially the protein level, they could be used for future development of serological-based diagnostics once monoclonal antibodies are developed for the $P$. cubensis-specific protein. A clear advantage of serological diagnostics is that it can be incorporated in field-friendly formats that can be used directly by growers, extension agents, and agricultural consultants, as is the case with the Phytophthora ImmunoStrip (Adgia, Elkhart, IN) (De Boer and Lopez 2012).

Accurate and timely identification of plant pathogens is the first step toward successful mitigation of crop diseases (De Boer and Lopez 2012). In cucumber, downy mildew symptoms have very characteristic angular leaf spots delimited by leaf veins and profuse sporulation on the underside of the leaf, making diagnosis simple by visual means once the disease has $>30 \%$ of severity on a leaf (Fig. 1) (Holmes et al. 2015). However, diagnosis during early stages of infection when fungicide applications would be most effective, or in hosts such as watermelon were symptoms are nondescript, can be difficult and delay disease mitigation efforts (Holmes et al. 2015). Recently, $P$. cubensis was also reported to be seed borne as is the case with other downy mildew pathogens such as Peronospora belbahrii (Cohen et al. 2014). The contribution of seed borne inoculum to yearly cucurbit downy mildew epidemics remains unclear but movement of infected plant material likely plays a role in $P$. cubensis population changes in the United States (Cohen et al. 2014; Holmes et al. 2015). Molecular diagnostics could be used for detection of early infections or infected seed in combination with appropriate sampling strategies, which would prevent pathogen introduction into new regions (De Boer and Lopez 2012). PCR assays with the seven nuclear genes identified in our study successfully detected $P$. cubensis in infected tissue of all plant hosts tested, including watermelon, which typically yields low quantities of pathogen DNA due to small lesions and poor sporulation of the pathogen on this host (Fig. 5).

Another common method to detect oomycetes is the use of spore traps, which is especially useful for monitoring airborne inoculum of downy mildew pathogens since many species are spread via airborne sporangia (Gent et al. 2009; Granke et al. 2013; Klosterman et al. 2014). In spore traps, pathogen sporangia are impacted on adhesive tape or grease covered rods on hourly, weekly, or daily time intervals that can later be stained and counted under a microscope (Jackson and Bayliss 2011). In U.S. states like
Michigan, a defined threshold of sporangia per week is used to determine when it is prudent to begin fungicide sprays for $P$. cubensis since sporangia concentrations are associated with the timing of downy mildew occurrence (Granke et al. 2014). A drawback of volumetric spore traps that has limited their deployment is the time and labor needed to enumerate sporangia (Granke and Hausbeck 2011), and often, morphological characters such as spore type and size, overlap between closely related organisms (Runge et al. 2012). Limitations of tape-based spore traps have been addressed in other downy mildew pathogens by combining spore trapping with molecular detection and quantification of the pathogen (Gent et al. 2009; Klosterman et al. 2014). Due to its usefulness in identification of fungi and oomycetes, ITS has become a common marker for diagnostics (Schoch et al. 2012), including many downy mildew pathogens (Belbahri et al. 2005; Feng et al. 2014; Gent et al. 2009; Hukkanen et al. 2006; Ioos et al. 2012; Klosterman et al. 2014; Montes-Borrego et al. 2010; Mota et al. 2011; Testen et al. 2013; Valsesia et al. 2005; Zipper et al. 2009). However, in closely related species there may be insufficient variability in the ITS (Gent et al. 2009; Klosterman et al. 2014), or copy number variation (Belbahri et al. 2008; Martin 1990) for useful delineation. Other assays utilizing locked nucleic acid probes and high resolution melt curve analysis can partially overcome this limitation, but add expense to the diagnostics (Summers et al. 2015). Two of the seven diagnostic markers identified in our study are putative single-copy markers (c2555.2e1 and c2555.3e7), making them attractive candidates for developing realtime PCR assays for $P$. cubensis inoculum monitoring efforts. Candidates c2555.2e1 and c2555.3e7 were also two of the three candidates that had no amplification in any $P$. humuli samples tested under the PCR conditions and primers designed in this study (Fig. 5).

Beyond the traditional use of plant disease diagnostics for agricultural decision-making, the need for rapid diagnostics has dramatically increased due to globalization of agricultural products (De Boer and Lopez 2012). Losses due to invasive plant pathogens could be reduced if improved disease detection methods were available (De Boer and Lopez 2012). For obligate parasites, such as downy mildew pathogens, development and validation of molecular assays may be complicated by lack of available genetic material, minimal sequence data to identify diagnostic markers, and unresolved phylogenetic status within the different genera (Thines et al. 2009). NGS and bioinformatics approaches allowed us to develop diagnostic markers that can differentiate $P$. cubensis from $P$. humuli. The approach detailed in this study also may also be amenable to identifying strains or pathotypes of $P$. cubensis. Similar approaches can also be applied to other plant pathogens with scarce genomic resources for rapid development of diagnostic markers.

\section{ACKNOWLEDGMENTS}

We thank all the members of the Quesada lab for their valuable help, especially E. Wallace, M. Adams, C. Parada, and A. Rahman for technical assistance. We would like to acknowledge the technical assistance of N. Adair. This work was supported by the U.S. Department of Agriculture (USDA) Animal and Plant Health Inspection Service (APHIS) Awards 13-8130-0254-CA and 13-8130-0274-CA, the USDA North Carolina Department of Agriculture (NCDA) Specialty Crop Block Grant Program (SCBGP) Award 12-25-B-16-88, and USDA-Agricultural Research Service (ARS) under project numbers NC02418 and CRIS 2072-21000-04600 . The use of trade, firm, or corporation names in this publication is for the information and convenience of the reader. Such use does not constitute an official endorsement or approval by the USDA or the ARS of any product or service to the exclusion of others that may be suitable.

\section{LITERATURE CITED}

Adams, I. P., Glover, R. H., Monger, W. A., Mumford, R., Jackeviciene, E., Navalinskiene, M., Samuitiene, M., and Boonham, N. 2009. Next-generation sequencing and metagenomic analysis: a universal diagnostic tool in plant virology. Mol. Plant Pathol. 10:537-545. 
Altschul, S. F., Gish, W., Miller, W., Myers, E. W., and Lipman, D. J. 1990. Basic local alignment search tool. J. Mol. Biol. 215:403-410.

Anders, S., Pyl, P. T., and Huber, W. 2015. HTSeq-A Python framework to work with high-throughput sequencing data. Bioinformatics 31:166-169.

Andrews, S. 2012. FastQC A Quality Control Tool for High Throughput Sequence Data. Babraham Bioinformatics. Babraham Institute.

Baxter, L., Tripathy, S., Ishaque, N., Boot, N., Cabral, A., Kemen, E., Thines, M., Ah-Fong, A., Anderson, R., Badejoko, W., Bittner-Eddy, P., Boore, J. L., Chibucos, M. C., Coates, M., Dehal, P., Delehaunty, K., Dong, S., Downton, P., Dumas, B., Fabro, G., Fronick, C., Fuerstenberg, S. I., Fulton, L., Gaulin, E., Govers, F., Hughes, L., Humphray, S., Jiang, R. H., Judelson, H., Kamoun, S., Kyung, K., Meijer, H., Minx, P., Morris, P., Nelson, J., Phuntumart, V., Qutob, D., Rehmany, A., Rougon-Cardoso, A., Ryden, P., Torto-Alalibo, T., Studholme, D., Wang, Y., Win, J., Wood, J., Clifton, S. W., Rogers, J., Van den Ackerveken, G., Jones, J. D., McDowell, J. M., Beynon, J., and Tyler, B. M. 2010. Signatures of adaptation to obligate biotrophy in the Hyaloperonospora arabidopsidis genome. Science 330:1549-1551.

Belbahri, L., Calmin, G., Pawlowski, J., and Lefort, F. 2005. Phylogenetic analysis and real-time PCR detection of a presumbably undescribed Peronospora species on sweet basil and sage. Mycol. Res. 109:1276-1287.

Belbahri, L., McLeod, A., Paul, B., Calmin, G., Moralejo, E., Spies, C. F. J., Botha, W. J., Clemente, A., Descals, E., Sanchez-Hernandez, E., and Lefort, F. 2008. Intraspecific and within-isolate sequence variation in the ITS rRNA gene region of Pythium mercuriale sp. nov. Pythiaceae. FEMS Microbiol. Lett. 284:17-27.

Campbell, M. A., Zhu, W., Jiang, N., Lin, H., Ouyang, S., Childs, K. L., Haas, B. J., Hamilton, J. P., and Buell, C. R. 2007. Identification and characterization of lineage-specific genes within the Poaceae. Plant Physiol. 145: 1311-1322.

Choi, Y.-J., Hong, S.-B., and Shin, H.-D. 2005. A re-consideration of Pseudoperonospora cubensis and $P$. humuli based on molecular and morphological data. Mycol. Res. 109:841-848.

Cohen, Y., Rubin, A. E., Galperin, M., Ploch, S., Runge, F., and Thines, M. 2014. Seed transmission of Pseudoperonospora cubensis. PLoS One 9:e109766.

Cohen, Y., Whener, T. c., Ojiambo, P., Hausbeck, M., Quesada-Ocampo, L. M., Lebeda, A., Sierotzki, H., and Gisi, U. 2015. Resurgence of Pseudoperonospora cubensis - The agent of cucurbit downy mildew. Phytopathology 105:998-1012.

De Boer, S. H., and Lopez, M. M. 2012. New grower-friendly methods for plant pathogen monitoring. Annu. Rev. Phytopathol. 50:197-218.

Djalali Farahani-Kofoet, R., Romer, P., and Grosch, R. 2012. Systemic spread of downy mildew in basil plants and detection of the pathogen in seed and plant samples. Mycol. Prog. 11:961-966.

Feng, C., Mansouri, S., Bluhm, B. H., du Toit, L. J., and Correll, J. C. 2014. Multiplex real-time PCR assays for detection of four seedborne spinach pathogens. J. Appl. Microbiol. 117:472-484.

Fisher, M. C., Henk, D. A., Briggs, C. J., Brownstein, J. S., Madoff, L. C., McCraw, S. L., and Gurr, S. J. 2012. Emerging fungal threats to animal, plant and ecosystem health. Nature 484:186-194.

Fry, W., Birch, P., Judelson, H., Grünwald, N. J., Danies, G., Everts, K. L., Gevens, A. J., Gugino, B., Johnson, D. A., Johnson, S. B., McGrath, M., Myers, K. L., Ristaino, J. B., Secor, G. A., and Smart, C. D. 2015. Five reasons to consider Phytophthora infestans a re-emerging pathogen. Phytopathology 105:966-981.

Gascuel, Q., Martinez, Y., Boniface, M.-C., Vear, F., Pichon, M., and Godiard, L. 2015. The sunflower downy mildew pathogen Plasmopara halstedii. Mol. Plant Pathol. 16:109-122.

Gent, D. H., Nelson, M. E., Farnsworth, J. L., and Grove, G. G. 2009. PCR detection of Pseudoperonospora humuli in air samples from hop yards. Plant Pathol. 58:1081-1091.

Gent, D. H., and Ocamb, C. M. 2009. Predicting infection risk of hop by Pseudoperonospora humuli. Phytopathology 99:1190-1198.

Gent, D. H., Twomey, M. C., Wolfenbarger, S. N., and Woods, J. L. 2015. Preand post-infection activity of fungicides in control of hop downy mildew. Plant Dis. 99:858-865.

Granke, L. L., and Hausbeck, M. K. 2011. Dynamics of Pseudoperonospora cubensis sporangia in commercial cucurbit fields in Michigan. Plant Dis. 95:1392-1400.

Granke, L. L., Morrice, J. J., and Hausbeck, M. K. 2013. Relationships between airborne Pseudoperonospora cubensis sporangia, environmental conditions, and cucumber downy mildew severity. Plant Dis. 98:674-681.

Greub, G., Kebbi-Beghdadi, C., Bertelli, C., Collyn, F. o., Riederer, B. M., Yersin, C., Croxatto, A., and Raoult, D. 2009. High throughput sequencing and proteomics to identify immunogenic proteins of a new pathogen: The dirty genome approach. PLoS One 4:e8423.

Hannon, G. 2010. FASTX Toolkit. Cold Spring Harbor Laboratory, Cold Spring Harbor, NY.

Holmes, G., Ojiambo, P. S., Hausbeck, M., Quesada-Ocampo, L. M., and Keinath, A. P. 2015. Resurgence of cucurbit downy mildew in the United States: A watershed event for research and extension. Plant Dis. 99:428-441.
Homa, K., Barney, W. P., Ward, D. L., Wyenandt, C. A., and Simon, J. E. 2014. Evaluation of fungicides for the control of Peronospora belbahrii on sweet basil in New Jersey. Plant Dis. 98:1561-1566.

Huang, S., Li, R., Zhang, Z., Li, L., Gu, X., Fan, W., Lucas, W.J., Wang, X., Xie, B., Ni, P., Ren, Y., Zhu, H., Li, J., Lin, K., Jin, W., Fei, Z., Li, G., Staub, J., Kilian, A., van der Vossen, E.A.G., Wu, Y., Guo, J., He, J., Jia, Z., Ren, Y., Tian, G., Lu, Y., Ruan, J., Qian, W., Wang, M., Huang, Q., Li, B., Xuan, Z., Cao, J. A., Wu, Z., Zhang, J., Cai, Q., Bai, Y., Zhao, B., Han, Y., Li, Y.,Li, X.,Wang, S., Shi, Q., Liu, S., Cho, W. K., Kim, J.-Y., Xu, Y., Heller-Uszynska, K., Miao, H., Cheng, Z., Zhang, S., Wu, J., Yang, Y., Kang, H., Li, M., Liang, H., Ren, X., Shi, Z., Wen, M., Jian, M., Yang, H., Zhang, G., Yang, Z., Chen, R., Liu, S., Li, J., Ma, L., Liu, H., Zhou, Y., Zhao, J., Fang, X., Li, G., Fang, L., Li, Y., Liu, D., Zheng, H., Zhang, Y., Qin, N., Li, Z., Yang, G., Yang, S., Bolund, L., Kristiansen, K., Zheng, H., Li, S., Zhang, X., Yang, H., Wang, J., Sun, R., Zhang, B., Jiang, S., Wang, J., Du, Y., and Li, S. 2009. The genome of the cucumber, Cucumis sativus L. Nat. Genet. 41:1275-1281.

Hukkanen, A., Pietikainen, L., Karenlampi, S., and Kokko, H. 2006. Quantification of downy mildew (Peronospora sparsa) in Rubus species using real-time PCR. Eur. J. Plant Pathol. 116:225-235.

Ioos, R., Fourrier, C., Wilson, V., Webb, K., Schereffer, J. L., and de Labrouhe, D. T. 2012. An optimized duplex real-time PCR tool for sensitive detection of the quarantine oomycete Plasmopara halstedii in sunflower seeds. Phytopathology 102:908-917.

Jackson, S. L., and Bayliss, K. L. 2011. Spore traps need improvement to fulfil plant biosecurity requirements. Plant Pathol. 60:801-810.

Klosterman, S. J., Anchieta, A., McRoberts, N., Koike, S. T., Subbarao, K. V., Voglmayr, H., Choi, Y.-J., Thines, M., and Martin, F. N. 2014. Coupling spore traps and quantitative PCR assays for detection of the downy mildew pathogens of spinach (Peronospora effusa) and beet (P. schachtii). Phytopathology 104:1349-1359.

Lang, J. M., Hamilton, J. P., Diaz, M. G. Q., Van Sluys, M. A., Burgos, M. R. G., Vera Cruz, C. M., Buell, C. R., Tisserat, N. A., and Leach, J. E. 2010. Genomics-based diagnostic marker development for Xanthomonas oryzae pv. oryzae and X. oryzae pv. oryzicola. Plant Dis. 94:311-319.

Langmead, B., Trapnell, C., Pop, M., and Salzberg, S. L. 2009. Ultrafast and memory-efficient alignment of short DNA sequences to the human genome. Genome Biol. 10:R25.

Lin, H., Moghe, G., Ouyang, S., Iezzoni, A., Shiu, S.-H., Gu, X., and Buell, C. R. 2010. Comparative analyses reveal distinct sets of lineage-specific genes within Arabidopsis thaliana. BMC Evol. Biol. 10:41.

Links, M. G., Holub, E., Jiang, R. H., Sharpe, A. G., Hegedus, D., Beynon, E., Sillito, D., Clarke, W. E., Uzuhashi, S., and Borhan, M. H. 2011. De novo sequence assembly of Albugo candida reveals a small genome relative to other biotrophic oomycetes. BMC Genomics 12:503.

Martin, F. N. 1990. Variation in the ribosomal DNA repeat unit within singleoospore isolates of the genus Pythium. Genome 33:585-591.

Martin, M. 2012. Cutadapt removes adapter sequences from high-throughput sequencing reads. Bioinform. Action 17:10-12.

Martin, F. N., Abad, Z. G., Balci, Y., and Ivors, K. 2012. Identification and detection of Phytophthora: Reviewing our progress, identifying our needs. Plant Dis. 96:1080-1103.

Michelmore, R., and Wong, J. 2008. Classical and molecular genetics of Bremia lactucae, cause of lettuce downy mildew. Eur. J. Plant Pathol. 122:19-30.

Mitchell, M. N., Ocamb, C. M., Grünwald, N. J., Mancino, L. E., and Gent, D. H. 2011. Genetic and pathogenic relatedness of Pseudoperonospora cubensis and P. humuli. Phytopathology 101:805-818.

Montes-Borrego, M., Munoz-Ledesma, F. J., Jimenez-Diaz, R. M., and Landa, B. B. 2010. Real-time PCR quantification of Peronospora arborescens, the opium poppy downy mildew pathogen, in seed stocks and symptomless infected plants. Plant Dis. 95:143-152.

Mota, M., Caldeira, C., and Monteiro, A. A. 2011. Molecular detection of contaminating fungi in lettuce. Acta Hortic. 917:217-223.

Ojiambo, P. S., Gent, D. H., Quesada-Ocampo, L. M., Hausbeck, M. K., and Holmes, G. J. 2015. Epidemiology and population biology of Pseudoperonospora cubensis: A model system for management of downy mildews. Annu. Rev. Phytopathol. 53:223-246.

Ojiambo, P. S., Paul, P. A., and Holmes, G. J. 2010. A quantitative review of fungicide efficacy for managing downy mildew in cucurbits. Phytopathology 100:1066-1076.

Pallen, M. J., Loman, N. J., and Penn, C. W. 2010. High-throughput sequencing and clinical microbiology: Progress, opportunities and challenges. Curr. Opin. Microbiol. 13:625-631.

Quesada-Ocampo, L. M., Granke, L. L., Olsen, J., Gutting, H. C., Runge, F., Thines, M., Lebeda, A., and Hausbeck, M. K. 2012. The genetic structure of Pseudoperonospora cubensis populations. Plant Dis. 96:1459-1470.

Roberts, P. D., Raid, R. N., Harmon, P. F., Jordan, S. A., and Palmateer, A. J. 2009. First report of downy mildew caused by a Peronospora sp. on basil in Florida and the United States. Plant Dis. 93:199. 
Runge, F., Ndambi, B., and Thines, M. 2012. Which morphological characteristics are most influenced by the host matrix in downy mildews? A case study in Pseudoperonospora cubensis. PLoS One 7:e44863.

Runge, F., and Thines, M. 2009. A potential perennial host for Pseudoperonospora cubensis in temperate regions. Eur. J. Plant Pathol. 123:483-486.

Savory, E. A., Adhikari, B. N., Hamilton, J. P., Vaillancourt, B., Buell, C. R., and Day, B. 2012a. mRNA-Seq analysis of the Pseudoperonospora cubensis transcriptome during cucumber (Cucumis sativus L.) infection. PLoS One 7:e35796.

Savory, E. A., Granke, L. L., Quesada-Ocampo, L. M., Varbanova, M., Hausbeck, M. K., and Day, B. 2011. The cucurbit downy mildew pathogen Pseudoperonospora cubensis. Mol. Plant Pathol. 12:217-226.

Savory, E. A., Zou, C., Adhikari, B. N., Hamilton, J. P., Buell, C. R., Shiu, S.-H., and Day, B. 2012b. Alternative splicing of a multi-drug transporter from Pseudoperonospora cubensis generates an RXLR effector protein that elicits a rapid cell death. PLoS One 7:e34701.

Schoch, C. L., Seifert, K. A., Huhndorf, S., Robert, V., Spouge, J. L., Levesque, C. A., Chen, W., and Consortium, F. B. 2012. Nuclear ribosomal internal transcribed spacer (ITS) region as a universal DNA barcode marker for fungi. Proc. Natl. Acad. Sci. 109:6241-6246.

Studholme, D. J., Glover, R. H., and Boonham, N. 2011. Application of highthroughput DNA sequencing in phytopathology. Annu. Rev. Phytopathol. 49:87-105.

Summers, C. F., Adair, N. L., Gent, D. H., McGrath, M. T., and Smart, C. D. 2015. Pseudoperonospora cubensis and P. humuli detection using species- specific probes and high definition melt curve analysis. Can. J. Plant Pathol. 37:1-16.

Testen, A. L., del Mar Jiménez-Gasco, M., Ochoa, J. B., and Backman, P. A. 2013. Molecular detection of Peronospora variabilis in quinoa seed and phylogeny of the quinoa downy mildew pathogen in South America and the United States. Phytopathology 104:379-386.

Thines, M., Telle, S., Ploch, S., and Runge, F. 2009. Identity of the downy mildew pathogens of basil, coleus, and sage with implications for quarantine measures. Mycol. Res. 113:532-540.

Valsesia, G., Gobbin, D., Patocchi, A., Vecchione, A., Pertot, I., and Gessler, C. 2005. Development of a high-throughput method for quantification of Plasmopara viticola DNA in grapevine leaves by means of quantitative real-time polymerase chain reaction. Phytopathology 95:672-678.

Wallace, E., Adams, M., Ivors, K., Ojiambo, P. S., and Quesada-Ocampo, L. M. 2014. First report of Pseudoperonospora cubensis causing downy mildew on Momordica balsamina and M. charantia in North Carolina. Plant Dis. 98:1279.

Wallace, E. C., Adams, M., and Quesada-Ocampo, L. M. 2015. First report of downy mildew on buffalo gourd (Cucurbita foetidissima) caused by Pseudoperonospora cubensis in North Carolina. Plant Dis. 99:1861.

Zipper, R., Hammer, T., and Spring, O. 2009. PCR-based monitoring of recent isolates of tobacco blue mold from Europe reveals the presence of two genetically distinct phenotypes differing in fungicide sensitivity. Eur. J. Plant Pathol. 123:367-375. 